\title{
TINJAUAN ASPEK KUALIFIKASI PENDIDIK, PENGUASAAN TEKNOLOGI INFORMASI DAN KOMUNIKASI, SERTA SUPERVISI AKADEMIK TERHADAP KEMAMPUAN MANAJEMEN KELAS PADA GURU SEKOLAH DASAR DI UPT PPD KECAMATAN PUNDONG KABUPATEN BANTUL
}

\author{
Oleh: Siti Haryani \\ SD Kepuh \\ helnadhifah@yahoo.co.id
}

\begin{abstract}
The purpose of this study was to determine: (1) the influence of educator qualifications, the mastery of ICT, as well as academic supervision jointly against class management capabilities among elementary school teachers, (2) the effect of educator qualifications on classroom management skills in an elementary school teacher, (3) the effect of mastery of ICT on classroom management skills in an elementary school teacher, and (4) the effect academic supervision of classroom management capabilities at an elementary school teacher. This study applied the quantitative approach using the survey design. The population in this research was all elementary school teachers in UPT PPD Pundong, Bantul regency, in the academic year of 2017/2018, amounting to as much as 182 teachers distributed in 19 elementary schools. Samples in this study were 124 teachers, taken by proportional random sampling method. Data collection used questionnaires. The data analysis was conducted on the descriptive analysis, linearity and multicollinearity test, multiple regression analysis, partial correlation analysis, and donations predictors include effective contribution and relative contribution. The results showed that the educator qualifications, mastery of ICT and academic supervision simultaneously have a very significant positive influence to the ability of teachers in classroom management. It means that if educator qualifications, mastery of ICT, and academic supervision become better, the ability of teachers to manage the classroom will become better too. Partially, the educator qualifications have a very significant positive influence to the ability of teachers to manage the classroom. The mastery of ICT also has a significant positive effect on the ability of teachers in classroom management. As well as a partial academic supervision also has a very significant positive influence on the ability of teachers in classroom management. Therefore, it is necessary to improve the educator qualifications, mastery of ICT, and academic supervision to increase the ability of teachers in classroom management.
\end{abstract}

Keywords: classroom management skills, educator qualifications, mastery of ICT, academic supervision

\section{PENDAHULUAN}

Guru merupakan ujung tombak dalam pendidikan. Berbagai bidang ilmu yang diterapkan di berbagai jenjang pendidikan tidak dapat mengabaikan peran guru. Guru sebagai pendidik merupakan sosok yang sangat penting bagi pengembangan potensi peserta didik. Kualitas proses pembelajaran di kelas yang dilakukan oleh guru, akan berdampak pada kualitas hasil belajar peserta didik. Berhasil tidaknya proses belajar mengajar ditentukan oleh kemampuan guru dalam memanajemen kelas. Terkait dengan pentingnya kedudukan pendidik tersebut, maka peran guru dalam suatu pembelajaran sangatlah penting dalam membantu peserta didik mencapai hasil belajar yang baik. Dalam proses tersebut, seorang guru perlu memperhatikan manajemen kelas yang akan digunakan. Hal ini disebabkan setiap manajemen kelas yang dilaksanakan oleh seorang guru dapat berpengaruh terhadap hasil belajar peserta didik. Harapan setiap peserta didik dalam kegiatan belajar mengajar adalah tingginya hasil belajar yang dicapai. Tingginya hasil ini selain usaha dari peserta didik untuk belajar mandiri, juga usaha atau bantuan dari pihak pendidik yaitu para guru 
dalam merancang manajemen kelas dalam pembelajaran.

Hasil belajar ditandai dengan adanya perubahan-perubahan pada diri peserta didik ke arah yang lebih baik dan dapat menerapkan apa yang telah dipelajarinya dalam kehidupan sehari-hari. Hasil belajar yang dicapai masingmasing peserta didik berbeda-beda, meskipun peserta didik mendapat kesempatan belajar yang sama. Peserta didik harus terus berusaha untuk meningkatkan hasil belajarnya, namun banyak hambatan yang dihadapi peserta didik dalam kegiatan belajarnya, sehingga nilai yang diperolehnya terkadang rendah. Hambatan tersebut diantaranya kemampuan guru dalam memanajemen kelas.

Banyak faktor yang mempengaruhi kemampuan guru dalam memanajemen kelas. Diantaranya kualifikasi akademik, penguasaan teknologi informasi dan komunikasi serta supervisi akademik. kualifikasi pendidik berkaitan dengan jenjang atau strata, penguasaan TIK berkaitan dengan kemampuan guru menggunakan perangkat TIK dalam membantu proses pembelajaran. Sedangkan supervisi akademik berkaitan dengan aktivitas pembinaan yang direncanakan untuk membantu para guru. Oleh karena itu, peneliti berminat melakukan penelitian dengan judul "Tinjauan aspek kualifikasi pendidik, penguasaan TIK serta supervisi akademik terhadap kemapuan manajemen kelas pada guru di UPT PPD Kecamatan Pundong Bantul tahun pelajaran 2017/2018.

\section{Landasan Teori}

Manajemen kelas adalah usaha sadar untuk mengatur kegiatan proses belajar mengajar secara sistematis.(Dadang Suhardan dkk, 2009:106). Manajemen kelas merupakan salah satu keterampilan yang harus dimiliki guru dalam memahami, mendiagnosis, memutuskan dan kemampuan bertindak menuju perbaikan suasana kelas yang dinamis (Mulyadi, 2009: 4). Selanjutnya Lemlech mengatakan bahwa "Classroom management is the orchestration of classroom life: planning curriculum, organizing procedures and resources, arranging the environment to maximize efficiency, monitoring student progress, anticipating potential problems". (Tabrani, 1994: 113). Menurut definisi ini, yang dimaksud dengan Manajemen Kelas adalah usaha dari pihak guru untuk menata kehidupan kelas dimulai dari perencanaan kurikulumnya, penataan prosedur dan sumber belajarnya, pengaturan lingkungannya untuk memaksimumkan efisiensi, memantau kemajuan siswa, dan mengantisipasi masalahmasalah yang mungkin timbul.

Dari beberapa pendapat para ahli diatas dan masih banyak lagi pendapat yang lain, maka dapat ditarik kesimpulan bahwa Manajemen Kelas merupakan upaya mengelola siswa didalam kelas yang dilakukan untuk menciptakan dan mempertahankan suasana/kondisi kelas yang menunjang program pengajaran dengan jalan menciptakan dan mempertahankan motivasi siswa untuk selalu ikut terlibat dan berperan serta dalam proses pendidikan di sekolah

Kualifikasi pendidik berkaitan erat dengan manajemen kelas. Makin tinggi tingkat pendidikan seseorang akan makin besar kecenderungannya untuk sukses di dalam kerjanya (Caplow, 1965: 31). Karena bidang pengetahuan apapun selalu mengalami perkembangan, maka seorang guru juga harus terus-menerus meningkatkan dan mengembangkan ilmu yang diajarkannya, sehingga tidak ketinggalan zaman. Guru menjadi aset strategis yang dituntut terus mengalami proses peningkatan pengetahuan dan keterampilan mengajar (on going formation) serta memiliki kemampuan untuk melihat ke depan (Drost, 2010: 156).

TIK sebagai media proses pembelajaran tempat guru mengajar dan siswa belajar. Menurut Kadir, "Peranan teknologi informasi dan komunikasi dalam bidang pendidikan akan melahirkan fitur-fitur baru dalam dunia pendidikan, misalnya sistem pengajaran 
berbasis multimedia (teknologi yang melibatkan teks, gambar, video, suara) sehingga guru dapat menyajikan materi dengan lebih menarik, tidak monoton, dan mempermudah penyajian." (Hamzah dan N. Lamatenggi, 2011: 107) Penerapan teknologi dan proses belajar mengajar dapat menigkatkan proses penetapan tujuan dengan menyediakan perangkat/alat komunikasi dan pengorganisasian yang menbuat lebih mudah (Suyanto, 185: 2013).

Supervisi akademik adalah supervisi yang menitikberatkan pengamatan pada masalah akademik yang langsung berada dalam lingkup kegiatan pembelajaran yang dilakukan oleh guru untuk membantu peserta didik ketika sedang dalam proses belajar (Arikunto, 2004: 5). Ruang lingkup pelaksanaan supervisi akademik yang dilaksanakan oleh pengawas meliputi kegiatan perencanaan proses belajar mengajar, pelaksanaan proses belajar mengajar dan penilaian proses belajar mengajar. Tujuan supervisi ialah memperkembangkan situasi belajar dan mengajar yang lebih baik (Purwanto, 2003: 23).

\section{Hipotesis Penelitian}

Hipotesis dapat diartikan sebagai suatu jawaban yang bersifat sementara terhadap permasalahan penelitian, sampai terbukti melalui data yang terkumpul (Arikunto, 2010:

64). Hipotesis yang dirumuskan dalam penelitian ini adalah sebagai berikut:

H1: Kualifikasi pendidik, penguasaan TIK, serta supervisi akademik secara bersamasama berpengaruh positif dan signifikan terhadap kemampuan guru dalam manajemen kelas di SD se-UPT PPD Pundong Kabupaten Bantul tahun pelajaran 2017/2018.

H2: Kualifikasi pendidik secara parsial berpengaruh positif dan signifikan terhadap kemampuan guru dalam manajemen kelas di SD se-UPT PPD Pundong Kabupaten Bantul tahun pelajaran 2017/2018.

H3: Penguasaan TIK secara parsial berpengaruh positif dan signifikan terhadap kemampuan guru dalam manajemen kelas di SD se-UPT PPD Pundong Kabupaten Bantul tahun pelajaran 2017/2018.

H4: Supervisi akademik secara parsial berpengaruh positif dan signifikan terhadap kemampuan guru dalam manajemen kelas di SD se-UPT PPD Pundong Kabupaten Bantul tahun pelajaran 2017/2018.

\section{METODE PENELITIAN}

Penelitian ini adalah penelitian kuantitatif, menggunakan desain penelitian survei .Populasi dalam penelitian ini adalah seluruh guru SD di UPT PPD Kecamatan Pundong Kabupaten Bantul yang berjumlah 182 yang tersebar di 19 Sekolah. Sampel pada penelitian ini adalah 124 guru yang diambil dengan metode proportional random sampling. Pengumpulan data dilakukan melalui penyebaran kuesioner. Analisis data yang dilakukan meliputi analisis deskriptif, uji prasyarat analisis mencakup uji normalitas, uji linieritas, dan uji multikolinieritas, analisis regresi berganda 3 prediktor dengan uji $\mathrm{F}$ dan uji determinasi, analisis korelasi parsial, dan sumbangan prediktor yang meliputi sumbangan efektif dan sumbangan relatif.

\section{HASIL DAN PEMBAHASAN}

\section{Uji Hipotesis 1}

Tabel 1. Hasil Uji F

\begin{tabular}{llrrrrrc}
\hline & Model & Sum of Squares & df & Mean Square & F & Sig. & Keterangan \\
\hline \multirow{2}{*}{1} & Regression & 7357,996 & 3 & 2452,665 & 26,975 & 0,000 & Sangat Signifikan \\
\cline { 2 - 8 } & Residual & 10910,738 & 120 & 90,923 & & & \\
\cline { 2 - 8 } & Total & 18268,734 & 123 & & & & \\
\hline
\end{tabular}


Berdasarkan tabel diatas dapat diketahui bahwa hasil uji F menunjukkan nilai signifikansi yang lebih kecil dari 0,05 , yaitu 0,000 . Nilai signifikansi yang lebih kecil dari 0,05 tersebut menunjukkan bahwa kualifikasi Pendidik, penguasaan TIK, dan supervisi akademik secara bersama-sama memiliki pengaruh yang sangat signifikan terhadap kemampuan guru memanajemen kelas. Dengan demikian, hipotesis H1 penelitian dapat diterima, yaitu "Kualifikasi Pendidik, penguasaan TIK, serta supervisi akademik secara bersama-sama berpengaruh positif dan sangat signifikan terhadap kemampuan guru dalam manajemen kelas di SD se-UPT PPD Pundong Kabupaten Bantul tahun pelajaran 2017/2018". Hasil uji F ini juga menunjukkan bahwa model regresi yang diperoleh sudah tepat sebagai model untuk memprediksi kemampuan guru memanajemen kelas pada SD Negeri Di UPT PPD Kecamatan Pundong Kabupaten Bantul Tahun Pelajaran 2017/2018.

Dari hasil perhitungan diketahui bahwa nilai koefisien determinan $\mathrm{R}^{2}$ adalah sebesar 0,403. Hal ini berarti bahwa sekitar 40,3\% kemampuan guru memanajemen kelas SD Di UPT PPD Kecamatan Pundong Kabupaten Bantul Tahun Pelajaran 2017/2018 secara langsung dipengaruhi oleh variabel prediktor yang diestimasi, yaitu Kualifikasi pendidik, penguasaan TIK, dan supervisi akademik guru. Namun demikian, sebanyak 59,7\% dipengaruhi oleh faktor lainnya yang tidak ikut serta diestimasi dalam model analisis regresi berganda yang dilakukan.

\section{Uji Hipotesis 2}

Hasil analisis korelasi parsial sebagai berikut:

Tabel 2. Hasil Analisis Korelasi Parsial X1

\begin{tabular}{lccrcc}
\hline \multirow{2}{*}{ Model } & \multirow{2}{*}{ Sig. } & Zero-order & Partial & Keterangan \\
\cline { 4 - 6 } & Kualifikasi Pendidik(X1) & 0,000 & 0,389 & 0,415 & Sangat Signifikan \\
\hline 1 & & & & \multicolumn{2}{c}{ Sumber: data diolah (2016) }
\end{tabular}

Pembuktian hipotesis 2 penelitian dapat diketahui dari nilai signifikansi. Berdasarkan tabel di atas dapat dilihat bahwa koefisien korelasinya adalah 0,415 dengan nilai signifikansi 0,000. Nilai signifikansi kurang dari 0,05 menunjukkan bahwa hubungan yang terjadi antara kualifikasi pendidik dengan kemampuan guru dalam manajemen kelas adalah hubungan yang sangat signifikan. Dengan demikian, hipotesis 2 penelitian dapat diterima, yaitu: "kualifikasi pendidik secara parsial berpengaruh positif dan sangat sifnifikan terhadap kemampuan guru dalam manajemen kelas di SD se- UPT PPD Kecamatan Pundong Kabupaten Bantul tahun pelajaran 2017/2018". Artinya semakin tinggi kualifikasi pendidik seorang guru, maka semakin tinggi pula kemampuan guru dalam memanajemen kelas. Demikian pula sebaliknya semakin rendah Kualifikasi pendidik seorang guru, maka semakin rendah pula kemampuan guru tersebut dalam memanajemen kelas.

Dari hasil perhitungan diketahui bahwa nilai koefisien korelasi Zero-order sebesar 0,389 , sedangkan setelah variabel Kualifikasi pendidik dikendalikan, nilai koefisien korelasi menjadi sebesar 0,415. Dengan demikian, terjadi peningkatan korelasi setelah adanya variabel penguasaan TIK dan supervisi akademik yang mengendalikan atau konstan. Dengan demikian, dapat dipahami bahwa jika penguasaan TIK dan supervisi akademik adalah konstan, maka hubungan positif antara Kualifikasi pendidik dengan kemampuan guru memanajemen kelas akan meningkat. Hasil ini menunjukkan bahwa hubungan antara Kualifikasi pendidik dan kemampuan guru memanajemen kelas tidak dikendalikan oleh penguasaan TIK dan supervisi akademik 


\section{Uji Hipotesis 3}

Hasil analisis korelasi parsial sebagai berikut:

Tabel 3. Hasil Analisis Korelasi Parsial X2

\begin{tabular}{lllrrrr}
\hline & \multirow{2}{*}{ Model } & \multirow{2}{*}{ Sig. } & \multicolumn{3}{c}{ Correlations } \\
\cline { 4 - 6 } & & & Zero-order & Partial & Keterangan \\
\hline 1 & $\begin{array}{l}\text { Penguasaan Teknologi } \\
\text { dan komunikasi (X2) }\end{array}$ & informasi & 0,036 & 0,418 & 0,190 & Signifikan \\
\hline
\end{tabular}

Berdasarkan tabel di atas dapat dilihat bahwa koefisien korelasinya adalah 0,190 dengan nilai signifikansi 0,036. Nilai signifikansi kurang dari 0,05 menunjukkan bahwa hubungan yang terjadi antara penguasaan TIK dengan kemampuan guru dalam manajemen kelas adalah hubungan yang signifikan. Dengan demikian, hipotesis 3 penelitian dapat diterima, yaitu: "penguasaan TIK secara parsial berpengaruh positif dan signifikan terhadap kemampuan guru dalam manajemen kelas di SD se- UPT PPD Kecamatan Pundong Kabupaten Bantul tahun pelajaran 2017/2018". Artinya semakin tinggi penguasaan TIK seorang guru, maka semakin tinggi pula kemampuan guru dalam memanajemen kelasnya. Demikian pula sebaliknya semakin rendah penguasaan TIK seorang guru maka semakin rendah pula
Sumber: data diolah (2016)

kemampuan guru dalam memanajemen kelasnya.

Dari tabel di atas dapat dilihat koefisien korelasi Zero-order sebesar 0,418, sedangkan setelah variabel penguasaan TIK dikendalikan, nilai koefisien korelasi menjadi sebesar 0,190. Dengan demikian, terjadi penurunan korelasi setelah adanya variabel Kualifikasi pendidik dan supervisi akademik yang megendalikan atau konstan. Dengan demikian, dapat dipahami bahwa jika Kualifikasi pendidikdan supervisi akademik adalah konstan, maka hubungan positif antara penguasaan TIK dengan kemampuan guru memanajemen kelas akan menurun. Hasil ini menunjukkan bahwa hubungan antara penguasaan TIK dan kemampuan guru memanajemen kelas dikendalikan oleh Kualifikasi pendidik dan supervisi akademik.

\section{Uji Hipotesis 4}

Hasil analisis korelasi parsial sebagai berikut:

Tabel 4. Hasil Analisis Korelasi Parsial X3

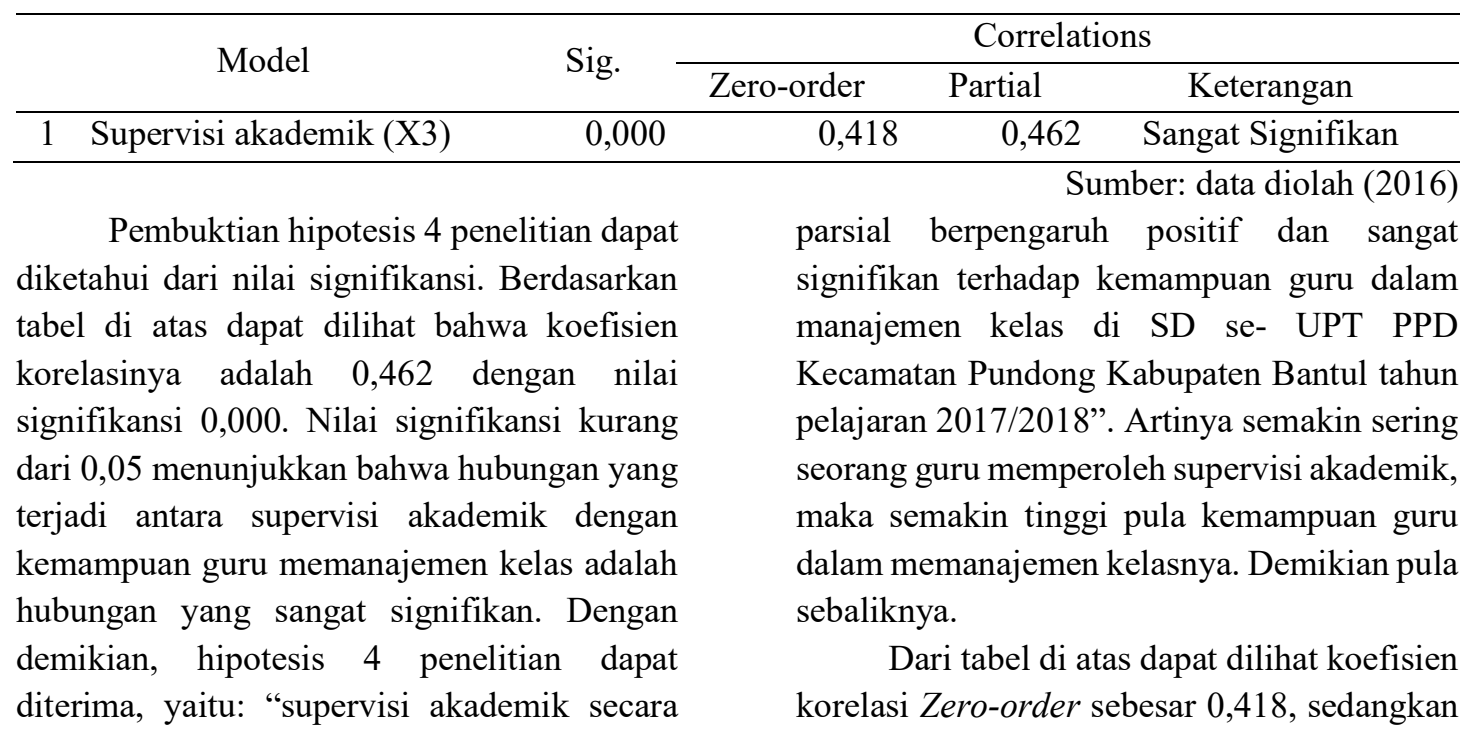


setelah variabel supervisi akademik dikendalikan, nilai koefisien korelasi menjadi sebesar 0,462. Dengan demikian, terjadi peningkatan korelasi setelah adanya variabel Kualifikasi pendidik dan penguasaan TIK yang megendalikan atau konstan. Dengan demikian, dapat dipahami bahwa jika Kualifikasi pendidikdan penguasaan TIK adalah konstan, maka hubungan positif antara supervisi akademik dengan kemampuan guru memanajemen kelas akan meningkat. Hasil ini menunjukkan bahwa hubungan antara supervisi akademik dan kemampuan guru memanajemen kelas tidak dikendalikan oleh Kualifikasi pendidikdan penguasaan TIK. Hasil penelitian membuktikan bahwa kualifikasi pendidik, penguasaan TIK, dan supervisi akademik berpegaruh secara bersama-sama terhadap kemampuan guru memanajemen kelas.

Peningkatan kemampuan guru dalam memanajemen kelas bisa dilakukan melalui peningkatan kualifikasi pendidik. Dimana Semakin tinggi kualifikasi pendidik seorang guru maka kemampuan guru dalam memanajemen kelas semakin tinggi. Hal ini disebabkan karena selama mengikuti pendidikan baik di bangku sekolah maupun di bangku kuliah semakin banyak guru memperoleh materi tentang bagaimana memanajemen kelas. Dengan kualifikasi pendidik yang lebih tinggi, guru akan memiliki kemampuan yang lebih baik dalam memanajemen kelas.

Penguasaan Teknologi informasi dan komunikasi banyak membantu dalam proses pembelajaran. Sistem belajar di sekolah yang selama ini monoton dan terkesan membosankan, dengan adanya dukungan penggunaan teknologi informasi dan komunikasi, misalnya guru memanfatkan peralatan audio visual (berbasis multimedia) dapat menjadi lebih menarik bagi siswa. Siswa cenderung senang dan tidak bosan belajar dikelas. Sehingga kelas menjadi tempat yang menyenangkan.
Guru yang menguasai TIK cenderung memiliki kemampuan untuk memanajemen kelas menjadi lebih baik. Dengan teknologi teknologi informasi dan komunikasi guru mampu memanfaatkan fitur-fitur baru dalam dunia pendidikan, misalnya sistem pengajaran berbasis multimedia (teknologi yang melibatkan teks, gambar, video, suara) sehingga guru dapat menyajikan materi dengan lebih menarik, tidak monoton, dan mempermudah penyajian.

Penguasaan TIK bagi guru sangat penting, karena merupakan salah satu faktor yang dapat mempengaruhi kemampuan guru dalam memanajemen kelas. Berdasarkan hasil penelitian diketahui bahwa penguasaan guru terhadap teknologi informasi dan komunikasi sudah terbilang baik. Pemanfaatan teknologi informasi dan komunikasi dalam dunia pendidikan memiliki tujuan yaitu membantu masalah-masalah yang terjadi terutama saat proses mengajar untuk mencapai target-target tententu yang diinginkan oleh guru. Teknologi pembelajaran yaitu sistem yang diciptakan oleh manusia untuk sesuatu tujuan tertentu, yang pada intinya adalah mempermudah manusia dalam memperingan usahanya. Dalam era perkembangan teknologi guru dituntut mampu untuk mengoperasikan komputer/laptop, jadi alangkah lebih baik jika guru mampu membuat media-media pengajaran berbasiskan komputer/laptop, minimal guru mampu mengakses informasi tentang perkembangan mata pelajaran yang diajarkannya melalui internet. Dengan menguasai TIK, seorang guru akan mampu memanfaatkan TIK sebagai objek pembelajaran yang kebanyakan terorganisasi dalam berbagai mata pelajaran khusus untuk mendapatkan literasi dalam bidang TIK. Apa yang dipelajari bergantung pada bentuk pendidikan dan level siswa. Pendidikan ini mempersiapkan siswa untuk menggunakan TIK dalam pendidikan, ketrampilan masa depan, dan kehidupan social. Selain itu, TIK bisa menjadi alat bantu, misalnya ketika 
membuat tugas, mengumpulkan data dan dokumentasi, serta melaksanakan penelitian. TIK juga bisa dimanfaatkan untuk memecahkan permasalahan secara mandiri, serta bisa sebagai media pembelajaran.

Dengan memanfaatkan TIK guru mampu menyediakan isi pelajaran, memproses tugas - tugas pembelajaran, mendukung berbagai metode mengajar, alat untuk menggugah pikiran dan motivasi. Hal ini akan berdampak pada peningkatan kemampuan manajemen kelas.

Upaya peningkatan mutu pendidikan dipengaruhi oleh banyak faktor. Faktor yang satu saling berpengaruh terhadap faktor yang lainnya. Namun demikian, faktor yang paling penting adalah guru, karena hitam-putihnya proses belajar mengajar di dalam kelas banyak dipengaruhi oleh kemampuan guru memanajemen kelasnya. Guru dikenal sebagai 'hidden currickulum' atau kurikulum tersembunyi, karena sikap dan tingkah laku, penampilan profesional, kemampuan parsial, dan apa saja yang melekat pada pribadi sang guru, akan diterima oleh peserta didiknya sebagai rambu-rambu untuk diteladani atau dijadikan bahan pembelajaran. Bagi sebagian besar orangtua siswa, sosok pendidik atau guru masih dipandang sebagai wakil orangtua ketika anak-anak tidak berada di dalam keluarga.

Pada era teknologi informasi, guru memang tidak lagi dapat berperan sebagai satu-satunya sumber informasi dan ilmu pengetahuan. Peran guru telah berubah lebih menjadi fasilitator, motivator, dan dinamisator bagi peserta didik. Dalam era teknologi informasi, guru dengan mudah dapat mengakses informasi apa saja yang tersedia melalui internet. Dengan kondisi seperti itu, maka guru harus memperoleh pelatihan teknologi informasi, mengikuti workshop dalam rangka penggunaan teknologi informasi, dan disediakan sarana dan prasarana terkait dengan teknologi informasi. Hal ini diharapkan dapat meningkatkan kemampuan guru memanajemen kelas.
Dalam penelitian ini telah dilakukan analisis terhadap data yang diperoleh guna mengetahui pengaruh supervisi akademik terhadap kemampuan guru memanajemen kelas pada SD di UPT PPD Kecamatan Pundong Kabupaten Bantul Tahun Pelajaran 2016/2017. Hasil analisis derksiptif telah menggambarkan data mengenai kondisi dari variabel penelitian. Berdasarkan hasil analisis dapat diketahui bahwa supervisi akademik dinilai baik oleh mayoritas guru SD Negeri di UPT PPD Kecamatan Pundong Kabupaten Bantul Tahun Pelajaran 2016/2017. Ada banyak indikator yang menandakan bahwa kepala sekolah sudah melaksanakan supervisi dengan baik.

Intensitas supervisi akademik yang sangat baik mencakup kemampuan kepala sekolah dalam merencanakan seluruh kegiatan supervisi, mengorgansiasiakan bahan dan instrumen yang dibutuhkan, melaksanakan supervisi sesuai perencanaan, serta melakukan evaluasi terhadap hasil supervisi. Kepala sekolah telah memiliki kemampuan yang baik dalam menyusun perencanaan supervisi untuk berbagai tingkatan supervisi. Selain itu, kepala sekolah juga mengembangkan pengorganisasian kegiatan supervisi sesuai dengan teknik supervisi yang efektif. Kepala sekolah juga menjadi pemimpin yang mampu menciptakan hubungan baik dengan guru sehingga guru tidak merasa diawasi dan dicari kesalahannya ketika pelaksanaan supervisi.

Konsep supervisi akademik tersebut merupakan salah satu faktor yang mempengaruhi kemampuan guru memanajemen kelas. Perubahan paradigma penyelenggaraan pendidikan dari sentralisasi ke desentralisasi telah mendorong terjadinya perubahan dan pembaharuan pada beberapa aspek pendidikan, termasuk pula dalam upaya membina dan meningkatkan kemampuan guru memanajemen kelas yang dilakukan oleh kepala sekolah. Kompetensi supervisi merupakan satu kemampuan yang harus dimiliki oleh seorang kepala sekolah setelah 
kompetensi pedagogik, kepribadian, sosial, dan profesional. Kepengawasan di sekolah yang dilakukan secara terus menerus setiap saat dilakukan oleh seorang kepala sekolah, sedangkan yang insidental dan tidak langsung dilakukan oleh seorang pengawas sekolah.

Pendidikan dapat dipahami merupakan usaha sadar yang dengan sengaja dirancangkan untuk mencapai tujuan yang telah ditetapkan. Tujuan pendidikan secara umum adalah untuk meningkatkan kemampuan guru memanajemen kelas sebagai sumber daya manusia. Peningkatan kemampuan guru memanajemen kelas akan mempengaruhi pencapaian tujuan pendidikan. Dalam proses upaya peningkatan mutu pendidikan, guru merupakan komponen sumber daya manusia yang harus dibina dan dikembangkan terus-menerus. Pembinaan kedinasan yang sudah berjalan demi pembentukan profesi guru dilaksanakan melalui program pendidikan pra-jabatan serta program pembinaan dalam jabatan. Ada juga PLPG dalam sertifikasi, atau pembinaanpembinaan melalui penataran-penataran peningktan kemampuan guru memanajemen kelas. Hal tersebut mengindikasikan bahwa tidak semua guru yang dididik di lembaga pendidikan terlatih dengan baik dan qualified. Potensi sumber daya guru itu perlu terus bertumbuh dan berkembang agar dapat melakukan fungsinya secara potensial. Selain itu pengaruh perubahan yang serba cepat mendorong guru-guru untuk terus-menerus belajar menyesuaikan diri dengan perkembangan ilmu pengetahuan dan teknologi serta mobilitas masyarakat.

Sebagian besar masyarakat mempercayai, mengakui dan menyerahkan kepada guru untuk mendidik putra-putrinya sebagai tunastunas muda harapan bangsa dan membantu mengembangkan potensinya secara proforsional. Kepercayaan, keyakinan, dan penerimaan ini merupakan substansi dari pengakuan masyarakat terhadap profesi guru. Implikasi dari pengakuan tersebut mengisyaratkan guru harus memiliki kualitas yang memadai. Tidak hanya pada tataran normatif saja namun mampu mengembangkan kompetensi yang dimiliki, baik kompetensi personal, professional, maupun kemasyarakatan dalam selubung aktualisasi kebijakan pendidikan.

Hal tersebut lantaran guru merupakan penentu keberhasilan pendidikan melalui kinerjanya pada tataran institusional dan eksperiensial, sehingga upaya meningkatkan mutu pendidikan harus dimulai dari aspek "guru" dan tenaga kependidikan lainnya yang menyangkut kualitas keprofesionalannya dalam satu manajemen pendidikan yang professional. Sebagai salah satu sumber acuan dalam pengembangan profesional guru, penting rasanya diefektifkan dimensi kompetensi supervisi akademik oleh kepala sekolah. Dengan memaksimalkan kegiatan supervisi akademik oleh kepala sekolah di tingkat satuan pendidikan, diharapkan guru dapat menjadi lebih bermutu melalui penguasaan peningkatan pengetahuan dan keterampilan dalam proses pembelajaran secara maksimal, seperti halnya menerapkan teknologi informasi dalam pembelajaran.

Supervisi akademik merupakan supervisi yang menitikberatkan pengamatan pada masalah akademik yang langsung berada dalam lingkup kegiatan pembelajaran yang dilakukan oleh guru untuk membantu peserta didik ketika sedang dalam proses belajar. Fungsi Supervisi akademik berkenaan dengan aspek pembinaan dan pengembangan kemampuan profesional guru dalam meningkatkan mutu pembelajaran dan bimbingan di sekolah. Dengan supervisi yang berkwalitas akan mampu meningkatkan kemampuan memanajemen kelas.

\section{KESIMPULAN}

Kesimpulan yang diperoleh dari hasilhasil penelitian ini diuraikan sebagai berikut:

a. Kualifikasi pendidik, penguasaan TIK, dan supervisi akademik secara bersama-sama 
berpengaruh positif dan sangat signifikan terhadap kemampuan manajemen kelas pada guru SD di UPT PPD Kecamatan Pundong Kabupaten Bantul. Kualifikasi pendidik, penguasaan TIK, dan supervisi akademik secara bersama-sama berpengaruh sangat signifikan terhadap kemampuan memanajemen kelas guru SD di UPT PPD Kecamatan Pundong Kabupaten Bantul. Artinya semakin tinggi kualifikasi pendidik, penguasaan TIK, dan supervisi akademik seorang guru maka kemampuaan memanajemen kelas guru semakin baik pula. Demikian juga sebaliknya semakin rendah Kualifikasi pendidik, penguasaan TIK, dan supervisi akademik seorang guru maka kemampuaan memanajemen kelas guru juga akan rendah.

b. Kualifikasi pendidik secara parsial berpengaruh positif dan sangat signifikan terhadap kemampuan manajemen kelas pada guru SD di UPT PPD Kecamatan Pundong Kabupaten Bantul. Pengujian hipotesis membuktikan bahwa Terdapat pengaruh positif dan sangat signifikan kualifikasi akademik terhadap kemampuan manajemen kelas pada guru SD di UPT PPD Kecamatan Pundong Kabupaten Bantul Tahun Pelajaran 2017/2018, menunjukkan bahwa semakin tinggi kualifikasi pendidik seorang guru, maka semakin tinggi pula kemampuan guru dalam memanajemen kelas. Demikian pula sebaliknya semakin rendah Kualifikasi pendidik seorang guru, maka semakin rendah pula kemampuan guru tersebut dalam memanajemen kelas.

c. Penguasaan TIK secara parsial berpengaruh positif dan signifikan terhadap kemampuan manajemen kelas pada guru SD di UPT PPD Kecamatan Pundong Kabupaten Bantul Tahun Pelajaran 2017/2018. Terdapat pengaruh positif dan signifikan penguasaan TIK terhadap kemampuan manajemen kelas pada guru SD di UPT PPD Kecamatan
Pundong Kabupaten Bantul Tahun Pelajaran 2017/2018. Pengaruh positif penguasaan TIK menunjukkan bahwa semakin baik penguasaan TIK, maka semakin baik pula kemampuan manajemen kelas pada guru. Demikian pula sebaliknya semakin rendah penguasaan TIK, maka semakin rendah pula kemampuan manajemen kelas.

d. Supervisi akademik secara parsial berpengaruh positif dan sangat signifikan terhadap kemampuan manajemen kelas pada guru SD di UPT PPD Kecamatan Pundong Kabupaten Bantul Tahun Pelajaran 2017/2018.

Pengaruh positif dan sangat signifikan supervisi akademik menunjukkan bahwa semakin baik kualitas supervisi akademik yang dilaksanakan oleh pengawas dan kepala sekolah, maka semakin baik pula kemampuan manajemen kelas pada guru. Dalam arti, semakin tinggi skor supervisi akademik maka semakin tinggi pula skor kemampuan manajemen kelas pada guru juga semakin baik. Supervisi merupakan salah satu faktor yang mempengaruhi kemampuan manajemen kelas pada kegiatan akademik.

Saran yang diberikan terkait dengan hasil yang diperoleh melalui penelitian ini adalah sebagai berikut.

a. Supervisor / Kepala Sekolah di UPT PPD Kecamatan Pundong Kabupaten Bantul perlu mempertahankan serta mengoptimalkan baik kwantitas maupun kualitas supervisi akademik yang dilaksanakannya. Hal ini perlu dilakukan agar kemampuan manajemen kelas pada guru tidak turun.

b. Guru SD di UPT PPD Kecamatan Pundong Kabupaten Bantul, hendaknya selalu melakukan upayamengembangkan kemampuan dalam penguasaan TIK serta kualifikasi pendidik agar kemampuan memanajemen kelas juga semakin meningkat.

c. Peneliti selanjutnya diharapkan dapat 
melakukan peneliti lanjutan dengan topik yang relevan terhadap penelitian ini. Peneliti selanjutnya dapat menggunakan penelitian ini sebagai landasan untuk melakukan pengembangan dengan menambah jumlah variabel atau menambah jumlah variabel yan menjadi prediktor bagi kemampuan manajemen kelas pada guru.

\section{DAFTAR PUSTAKA}

Caplow,T, \& McGee.R. (1965), The academic marketplace.Garden City, NY:Anchor Books.

Cece Wijaya, A. Tabrani Rusyan. (1994). Kemampuan Dasar Guru Dalam Proses Belajar Mengajar .Bandung: Remaja Rosdakarya.

J. Drost.SJ. (1999). Proses Pembelajaran Sebagai Proses Pendidikan, Jakarta : gramedia.
Hamzah dan Nina Lamatenggo. (2011). Teknologi Komunikasi dan Informasi Pembelajaran. Jakarta: Bumi Aksara.

Mulyadi. (2009). Classroom Management Mewujudkan Suasana Kelas Yang Menyenagkan Bagi Siswa. Malang: Aditya Media.

Ngalim Purwanto. (1991). Administrasi dan Supervisi Pendidikan. Bandung: Remaja Rosdakarya.

Suhardan Dadang. (2010). Supervisi Profesional (Layanan dalam meningkatkan mutu pengajaran di Era Otonom Daerah). Bandung: Alfabeta.

Suharsimi Arikunto. (2004). Pengelolaan Kelas dan Siswa. Jakarta: Rineka Cipta.

Suyanto, Asep Jihad. (2013). Menjadi Guru Profesional: strategi memanfaatkan kualifikasi dan kualitas guru di Era globalisasi. Jakarta : Erlangga. 